\title{
Impact of residual fuel ash layers on the catalytic activation of K-feldspar regarding the water-gas shift reaction
}

\author{
Katharina Fürsatz ${ }^{1,2}$ (D) Matthias Kuba ${ }^{1,2}$ (D) - Daniel Janisch ${ }^{2} \cdot$ Kouessan Aziaba $^{2} \cdot$ Christoph Hammerl $^{2}$. \\ Damian Chlebda ${ }^{3} \cdot$ Joanna $Ł o j e w s k a^{3} \cdot$ Hermann Hofbauer $^{2}$ (I)
}

Received: 9 December 2019 / Revised: 8 February 2020 / Accepted: 16 February 2020 / Published online: 14 March 2020

(C) The Author(s) 2020

\begin{abstract}
Interaction of biomass ash and bed materials in thermochemical conversion in fluidized beds leads to changes of the bed particle surface due to ash layer formation. Ash components present on the bed particle surface strongly depend on the ash composition of the fuel. Thus, the residual biomass used has a strong influence on the surface changes on bed particles in fluidized bed conversion processes and, therefore, on the catalytic performance of the bed material layers. Ash layer formation is associated with an increase in the catalytic activity of the bed particles in gasification and plays a key role in the operability of different biomass fuels. The catalytic activation over time was observed for K-feldspar used as the bed material with bark, chicken manure, and a mixture of bark and chicken manure as fuels. The changes on the bed material surfaces were further characterized by SEM/ EDS and BET analyses. Raman, XPS, and XRD analyses were used to characterize the crystal phases on the bed material surface. An increase in surface area over time was observed for K-feldspar during the interaction with biomass ash. Additionally, a more inhomogeneous surface composition for fuels containing chicken manure in comparison to pure bark was observed. This was due to the active participation of phosphorus from the fuel ash in the ash transformation reactions leading to their presence on the particle surface. A decreased catalytic activity was observed for the same BET surface area compared to bark combustion, caused by the different fuel ash composition of chicken manure.
\end{abstract}

Keywords Biomass $\cdot$ Catalysis $\cdot$ Ash layer formation $\cdot$ Surface characterization $\cdot$ Water-gas shift

$\begin{array}{ll}\text { Abbreviations } \\ \text { B7C3 } & \begin{array}{l}0.7 \mathrm{~kg} \text { bark and } 0.3 \mathrm{~kg} \text { chicken manure per kilogram } \\ \text { of dry fuel }\end{array} \\ \text { BET } & \text { Brunauer-Emmett-Teller } \\ \mathrm{db} & \text { Dry basis } \\ \mathrm{DFB} & \text { Dual fluidized bed } \\ \text { EDS } & \text { Energy-dispersive X-ray spectroscopy }\end{array}$

Katharina Fürsatz

katharina.fuersatz@best-research.eu

Matthias Kuba

matthias.kuba@best-research.eu

1 BEST - Bioenergy and Sustainable Technologies GmbH, Inffeldgasse 21b, 8010 Graz, Austria

2 Institute of Chemical, Environmental \& Bioscience Engineering, Technische Universität Wien, Getreidemarkt 9/166, 1060 Vienna, Austria

3 Faculty of Chemistry, Jagiellonian University, Gronostajowa 2, 30-387 Kraków, Poland
MFC Mass flow controller

SEM Scanning electron microscopy

WGS Water-gas shift

XPS X-ray photoelectron spectroscopy

XRD X-ray diffraction

\section{Introduction}

Human activities since the age of industrialization are significantly influencing the Earth system, resulting in an environment that is less hospitable to the development of human societies. One of the main changes, where human action plays at least a significant part, is the rise of the global temperature [1]. The World Bank concluded that mitigating climate pollutants would at least significantly slow down the undesired climate change, which would decrease negative consequences for the human societies [2].

The thermochemical conversion of biomass, which is currently the main source of renewable energy globally [3], can 
play an important role in achieving this mitigation goal. Biomass is the only renewable carbon source and, thus, can be utilized for the production of a wide spectrum of different end products [4]. Steam gasification of biomass transforms the solid feedstock into a gaseous secondary energy carrier which enables the further production of electricity as net stabilizer, district heat, high-grade transportation fuels [5], pure hydrogen $[6,7]$, synthetic natural gas $[8,9]$, waxes, or synthetic chemicals [10]. More details regarding the state of the art in steam gasification was provided by Karl and Pröll in 2018 [11].

A dual fluidized bed (DFB) steam gasification process was developed at TU Wien [12]. The principle underpinning this process is the separation of endothermic gasification and exothermic combustion. The heat necessary for devolatilization and gasification is provided by circulating the bed material from the combustion to the gasification reactor. The bed material acts as a heat carrier and also as a catalyst in the gasification reactor. Steam is used as a fluidizing agent for the bubbling bed in the gasification reactor. Fast fluidization in the combustion reactor is realized by using air [12]. A part of the devolatilized biomass or biomass char is combusted to provide the heat necessary for gasification.

Biomass ash plays a major role in fluidized bed gasification, since it interacts with the bed material resulting in ash layer formation on the bed particle surface. A detailed assessment of the ash transformation reactions in thermochemical conversion of biomass was published by Boström et al. [13]. This ash layer formation has been studied for different types of bed materials, such as olivine [14], quartz [15], and K-feldspar $[16,17]$, describing the mechanisms underlying the formation of those layers. The mechanisms differentiate significantly from another in the initiating steps of the layer formation. The developing layers are normally labeled as inner layers. Outer layers are developed by fuel ash directly accumulating on the surface so the composition of the outer layers mainly correlates with the ash composition of the fuel [18, 19]. Most of the available literature is focused on phosphorus-lean fuels, but studies focusing on phosphorus-rich fuels have shown that the inner layer formation is highly influenced by the presence of phosphorus $[17,20]$. Layer-initiating elements like potassium and calcium normally react with silicone in the bed material, but when phosphorus is available, they will react with phosphorus instead, since it is more reactive [13].

Furthermore, the utilization of residual biomass of lower quality than stem-wood-based biomass is of high interest for improving the economic feasibility of the process as well as increasing the share of renewables in the energy mix. Previous studies have been focused on the use of, e.g., chicken manure, bark, straw, sugar cane bagasse, or exhausted olive pomace as residual biomass [21-23]. Different residual biomasses cannot be compared easily since their composition and fuel characteristics vary greatly. Biomass ash can range from silicone- rich (e.g., straw) and calcium-rich (e.g., bark) to containing considerable amounts of phosphorus (e.g., manures) [17]. The consequences of using residual biomass, regarding the surface composition of the ash-layered bed particles and the subsequent influence on the catalytic activation, have been studied occasionally $[24,25]$.

While studies referring to industrial-scale plants mainly focused on olivine as a bed material [26], several alternative bed materials have been studied in lab- to pilot-scale experiments, where an activation could be observed [16, 17, 27, 28]. Studies have shown that the layer formation during (steam) gasification is comparable to layer formation during combustion $[29,30]$. Only fuels rich in sulfur lead to different layers and agglomerates. During combustion, sulfur is retained in the ash to form various sulfates, while it is released in the gas phase during gasification [29]. More potassium and sodium are then available to react with the bed material to form, e.g., low-melting silicates in the case of a quartz bed.

It has been observed during steam gasification that an increase in the catalytic activity of bed particles due to layer formation leads to an improvement of the product gas quality $[31,32]$. The increase in catalytic activity toward gasification reactions was loosely associated with an enrichment of ash components on the particle's surface, mainly calcium [33, 34], potassium [35, 36], and sulfur [32]. Kirnbauer et al. observed a reduction of gravimetric tars of $65 \%$ when using used olivine in contrast to fresh olivine as bed material in a DFB steam gasification pilot plant [31].

Alkali-feldspar $\left(0.48 \mathrm{~kg} \mathrm{~kg}^{-1} \mathrm{~K}\right.$-feldspar, $0.40 \mathrm{~kg} \mathrm{~kg}^{-1} \mathrm{Na}-$ feldspar, $0.06 \mathrm{~kg} \mathrm{~kg}^{-1} \mathrm{Ca}$-feldspar, $0.06 \mathrm{~kg} \mathrm{~kg}^{-1}$ quartz) was tested for its applicability as a catalyst for product gas upgrading [28]. The catalytic activity for gasification applications is mainly characterized by the water-gas shift (WGS) reaction and tar reforming. The experiments showed a clear reduction in tar content and an increase of the $\mathrm{H}_{2} / \mathrm{CO}$ ratio from 0.7 to 3.0 (caused by an increase in the WGS reaction) in the product gas. Experimental campaigns using the same alkali-feldspar as bed material in DFB steam gasification further supported the catalytic activity observed before [37]. Faust et al. [38] and Hannl et al. [39] extensively studied the layer formation of alkali-feldspars obtained from DFB steam gasification experiments in a two-part study focusing on two separate feldspars, namely part 1, K-feldspar [38] and part 2, Na-feldspar [39]. While both feldspars formed a calcium-rich outer layer, an additional potassium-rich inner layer formed only on Na-feldspar particles. They concluded that due to the additional potassium-rich layer on Na-feldspar, K-feldspar is more stable, i.e., more suitable for fluidized bed applications.

Mauerhofer et al. tested K-feldspar $\left(0.87 \mathrm{~kg} \mathrm{~kg}^{-1} \mathrm{~K}\right.$-feldspar, $0.07 \mathrm{~kg} \mathrm{~kg}^{-1} \mathrm{Na}$-feldspar) as a bed material for DFB steam gasification and observed a low catalytic activity, compared to olivine and calcite [40]. Selective tests of the catalytic activity showed no activity regarding the WGS reaction [25] 
and tar reduction [41], though it was possible to observe an activation over time during DFB steam gasification with an ash-rich fuel mixture of bark, straw, and chicken manure [24]. The influence of phosphorus, originating from chicken manure, on layer formation on K-feldspar was studied for combustion and steam gasification atmosphere by Wagner et al. [27]. No differences in the layer formation mechanism could be observed between combustion and gasification; a difference could only be detected between phosphorus-lean and phosphorus-rich fuels. Even though layer formation on Kfeldspar was studied extensively, deeper knowledge about the correlation between surface morphology changes during layer formation and bed material catalytic activity is still missing.

This work, therefore, focuses on establishing a link between catalytic activity and surface composition and morphology on K-feldspar. Several fuels (i.e., bark, chicken manure, and a bark-chicken manure mixture) were used in combustion experiments to develop a fuel ash layer on K-feldspar. Sampling during the operation made it possible to study time-dependent changes in surface activation, composition, and morphology.

Better understanding the link between surface morphology and catalytic activity is hoped to make it possible to selectively manipulate layer formation in a way to be most beneficial in increasing the catalytic activity of a bed material for DFB steam gasification and also in responding rationally to any malfunctions during the process. K-feldspar was chosen due to its positive evaluation as an alternative bed material for DFB steam gasification. The bed material samples studied were collected over several hours from fluidized bed combustion with bark, chicken manure, and a mixture of bark and chicken manure, giving additional focus to residual biomass. The bed material activation was observed for increasing particle age by testing the catalytic activity regarding the WGS reaction. The changes in surface morphology were observed using scanning electron microscopy (SEM) and BrunauerEmmett-Teller (BET) analysis. The surface composition was characterized using energy-dispersive X-ray spectroscopy (EDS), and the crystal phases occurring on the surface were characterized using X-ray diffraction (XRD), X-ray photoelectron spectroscopy (XPS), and Raman analysis.

\section{Materials and methods}

\subsection{Bed material and fuel specifications}

Fresh and layered K-feldspar was studied as bed material in this study. It has been reported to be a potential alternative bed material in fluidized bed combustion and gasification [24, 28, 37]. K-feldspar has a Mohs hardness of 6, which is suitable for the application in fluidized bed conversion. The density of $\mathrm{K}$ - feldspar is $2600 \mathrm{~kg} \mathrm{~m}^{-3}$. The $\mathrm{K}$-feldspar used for this study consists of $0.87 \mathrm{~kg} \mathrm{~kg}^{-1} \mathrm{~K}$-feldspar, $0.07 \mathrm{~kg} \mathrm{~kg}^{-1} \mathrm{Na}$-feldspar, $0.04 \mathrm{~kg} \mathrm{~kg}^{-1}$ quartz, and $0.02 \mathrm{~kg} \mathrm{~kg}^{-1}$ clay substance as reported by the supplier.

Pure bark, pure chicken manure, and a mixture of $0.7 \mathrm{~kg} \mathrm{~kg}^{-1}$ (dry basis (db)) bark and $0.3 \mathrm{~kg} \mathrm{~kg}^{-1} \mathrm{db}$ chicken manure (B7C3) were used as fuels in combustion experiments in a bubbling fluidized bed at temperatures between 800 and $830^{\circ} \mathrm{C}$. Bed material samples were taken after $4,8,16,24,32$, and $40 \mathrm{~h}$, if possible. The combustion of pure bark and pure chicken manure were not performed for the planned $40 \mathrm{~h}$, due to complications. For these fuels, an additional sample is available from the premature end of the experiment. Figure 1 depicts the elemental composition of the fuel ash, produced at $550{ }^{\circ} \mathrm{C}$, measured by XRD, as well as the fuel ash content. A detailed overview of the experimental parameters as well as sampling conditions for the bed material samples was given by Wagner et al. [17].

\subsection{Catalytic activity tests}

The catalytic activity of the bed material samples was tested regarding the WGS reaction. The used micro-scale test-rig is depicted in Fig. 2. The CO flow was set to $10 \mathrm{NL} \mathrm{h}^{-1}$ with a mass flow controller (MFC), and $\mathrm{CO}$ was supplied from a gas bottle. CO was heated to $140{ }^{\circ} \mathrm{C}$. Demineralized water $\left(8 \mathrm{~g} \mathrm{~h}^{-1}\right)$ was supplied from a reservoir by pressing it out with pressurized $\mathrm{N}_{2}$. The water flow was selected in a way to reach a slight water excess. The water flow was controlled with a liquid MFC and evaporated (at $140{ }^{\circ} \mathrm{C}$ ) in a controlled evaporator mixer by Bronkhorst. The produced steam was mixed with $10 \mathrm{NL} \mathrm{h}^{-1}$ carrier gas $\left(\mathrm{N}_{2}\right)$. The steam/carrier gas mixture was then mixed with the preheated $\mathrm{CO}$ and led into a quartz glass reactor heated to $850^{\circ} \mathrm{C}$ by a heating furnace. The quartz glass reactor has an inner diameter of $4 \mathrm{~mm}$. Quartz wool was used to position the bed material sample inside the quartz glass reactor. The bed sample height used was $5 \mathrm{~cm}$. The tested bed material was sieved to a size of $200-250 \mu \mathrm{m}$. Thermocouples were positioned at the top and bottom of the fixed bed to observe the bed material temperature. The gas leaving the reactor was cooled in a laboratory cooler to condense all water before the gas was led into a Rosemount NGA 2000 fivecomponent online gas analyzer. The gases recorded were $\mathrm{CO}, \mathrm{CO}_{2}, \mathrm{CH}_{4}, \mathrm{H}_{2}$, and $\mathrm{O}_{2}$.

The experiments were performed for $2 \mathrm{~h}$ to observe the long-term behavior of the bed material particles. A few minutes after starting the experiment by leading $\mathrm{CO}$ and $\mathrm{H}_{2} \mathrm{O}$ into the reactor, the maximal $\mathrm{H}_{2}$ and $\mathrm{CO}_{2}$ concentrations were observed. To omit initial deactivation behavior, the evaluation was started 30 min after the maximal $\mathrm{H}_{2}$ and $\mathrm{CO}$ concentrations were reached. The values given in the results are average gas compositions observed for $1 \mathrm{~h}$ after these $30 \mathrm{~min}$. 
Fig. 1 Elemental composition of the fuel ash given in $\mathrm{mol} \mathrm{kg}^{-1}$ dry fuel as well as the fuel ash content given in $\mathrm{g} \mathrm{kg}{ }^{1}$ dry fuel. Reprinted from [17], Copyright (2019), with permission from Elsevier

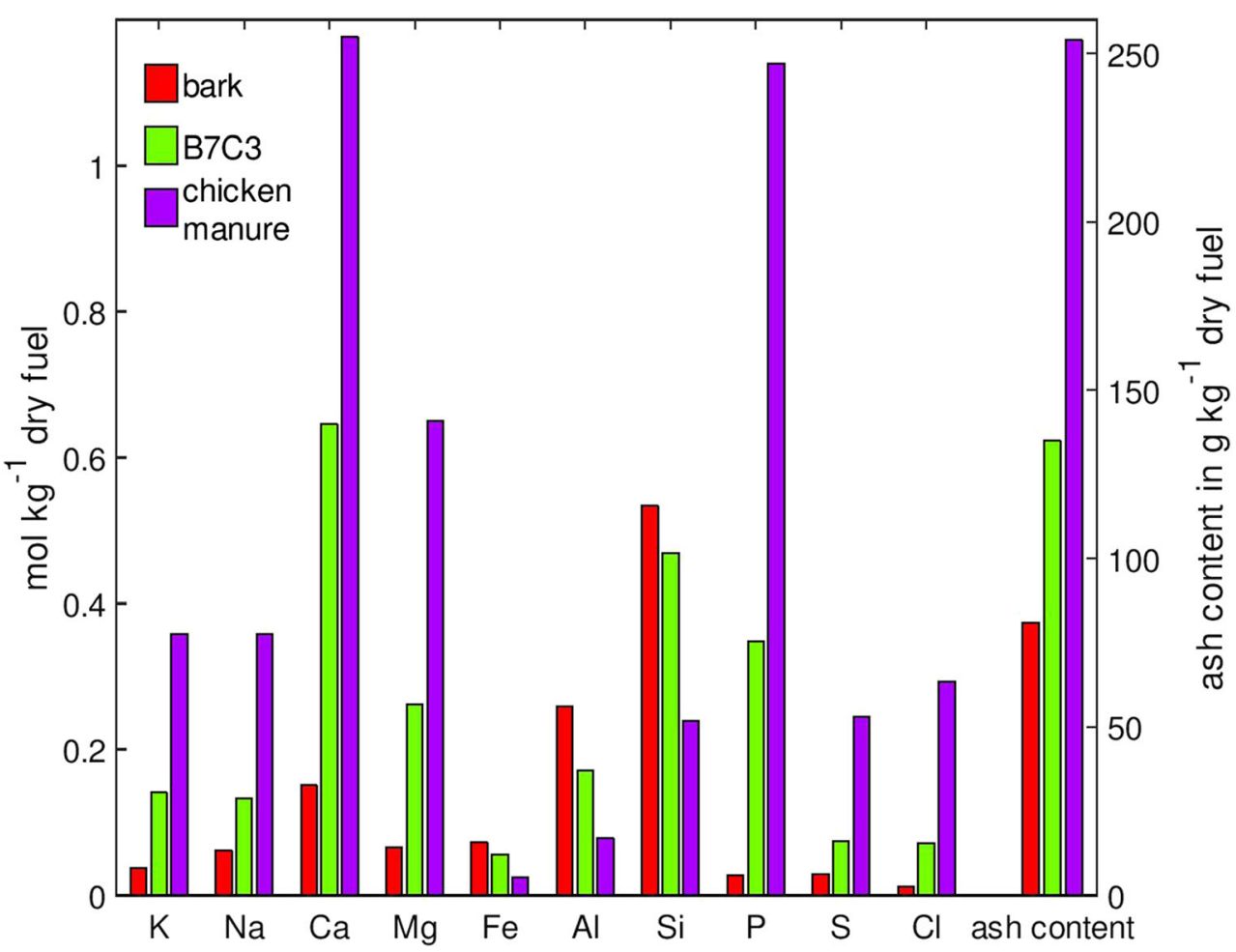

\subsection{SEM/EDS analysis}

Bed material samples were positioned on a sample holder and investigated using SEM/EDS analysis. The analysis was used to determine the chemical composition and morphology of the bed particle surface. EDS area analysis was used to determine the elemental composition. The surface morphology assessment was carried out with an FEI Quanta 200. Prior to

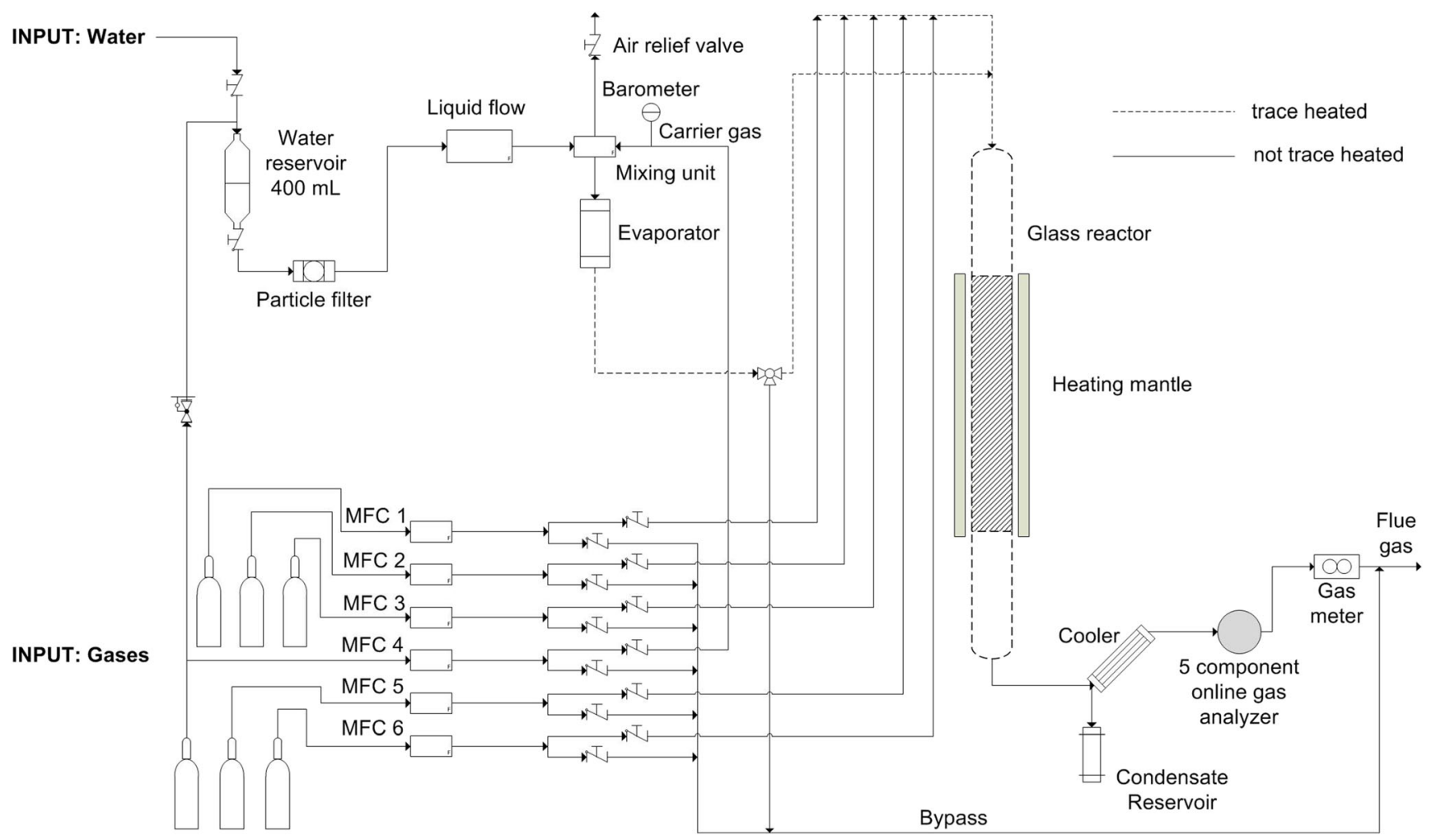

Fig. 2 Detailed flow sheet of the used micro-scale test-rig 
analysis, the samples were applied onto a graphite band and degassed at $10 \mathrm{~mA}$ and $0.1 \mathrm{mbar}$ for about $30 \mathrm{~s}$. The acceleration voltage ranged between 0.2 and $30 \mathrm{kV}$ but was typically set to $20 \mathrm{kV}$ since that yielded the best images. Measurements were operated in "low vacuum mode" at $80 \mathrm{~Pa}$. Secondary electron images were taken by the installed Large Field Detector, and backscattered electron images were taken by a Solid State Backscattered Electron Detector. EDS spectra were collected with an EDAX Genesis detector.

\subsection{BET analysis}

BET measurements were conducted with a Micromeritics ASAP 2020 V4.00 and nitrogen sorption at $77 \mathrm{~K}$. Prior to analysis, the samples were degassed under vacuum at $350{ }^{\circ} \mathrm{C}$ for $8 \mathrm{~h}$. Analyzed sample weights amounted to around $1000 \mathrm{mg}$.

\subsection{Raman analysis}

For Raman spectroscopy, a LabRAM HR800 confocal Raman microscope was used. The bed material particles were loaded without preparation in a reactor cell Linkam-CCR1000, fitted with quartz windows. The laser signal was calibrated at a pure silica specimen to $520.7 \mathrm{~cm}^{-1}$ Raman shift.

\subsection{XRD analysis}

XRD data were collected using a PANalytical Xpert Pro Diffractometer equipped with monochromatized $\mathrm{Cu} \mathrm{K} \alpha$ radiation $(\lambda=1.54 \AA)$. The analysis was carried out in the scan range from 5 to $65^{\circ} 2 \theta$ with a scanning step of $0.02^{\circ} 2 \theta$. The samples were measured without further preparation as grains. XRD analysis software HighScore by Malvern PANalytical was used for peak assignment [42].

\subsection{XPS analysis}

XPS was performed with an ESCA Prevac spectrometer equipped with a hemispheric analyzer of charged particles, an X-ray tube equipped with two anticathodes $(\mathrm{Mg} / \mathrm{Al})$, and an $\mathrm{X}$-ray monochromator with radiation source. Each XPS spectrum was calibrated to the carbon component $\mathrm{C} 1 \mathrm{~s}$ binding with an energy of $285.0 \mathrm{eV}$. The fitting of high-resolution spectra was done in CasaXPS software. All XPS measurements were performed directly without sample preparation.

\section{Results}

\subsection{Determination of catalytic activity}

Experiments were conducted to determine the catalytic activation of layered K-feldspar over time. Figure 3 gives the $\mathrm{H}_{2}$ yield relative to the WGS equilibrium concentration, when leading $\mathrm{CO}$ and $\mathrm{H}_{2} \mathrm{O}$ over the bed material samples. The correlation between particle age and $\mathrm{H}_{2}$ yield was determined according to the Kendall rank correlation. A $\tau$ value of 0.8 and a $p$ value well below 0.05 indicate a strong correlation between particle age and $\mathrm{H}_{2}$ yield. The determined $p$ value has to be studied carefully, since the evaluation of the Kendall rank correlation with several data points of the same $x$ value is only possible to a certain degree.

Fresh K-feldspar $(0 \mathrm{~h})$ showed nearly no catalytic activity. Already short operational times of $4 \mathrm{~h}$ led to an observable increase in catalytic activity for all fuels. The catalytic activity further increased for longer operational times. After $10 \mathrm{~h}$ of combustion, the highest catalytic activity can be observed for the bed material samples from pure chicken manure combustion. The combustion experiment with chicken manure had to be stopped prematurely due to operational problems, described in more detail by Wagner et al. [17]. For operational times of more than $10 \mathrm{~h}$, the samples from $\mathrm{B} 7 \mathrm{C} 3$ and bark combustion reached comparable $\mathrm{H}_{2}$ contents.

\subsection{Surface morphology}

Several bed material samples were chosen for further surface analyses to ascertain the influence of surface morphology and composition on the catalytic activity. The samples studied in more detail were fresh K-feldspar, the samples after $8 \mathrm{~h}$ of combustion with all three fuels, and the sample after $32 \mathrm{~h}$ of combustion with bark and $40 \mathrm{~h}$ of combustion with B7C3. The samples were selected since they were the last samples from scheduled sampling.

Figure 4 shows SEM images of the surface of different particles. Figure 4a shows the surface of fresh K-feldspar, where the crystal structure of K-feldspar on the surface is clearly observable. Figure $4 \mathrm{~b}$ and $\mathrm{c}$ show the result of interaction of K-feldspar with bark after $8 \mathrm{~h}$ and $32 \mathrm{~h}$, respectively, Fig. $4 \mathrm{~d}$ and e show the interaction with B7C3 after $8 \mathrm{~h}$ and $40 \mathrm{~h}$ of interaction, respectively, and Fig. $4 \mathrm{f}$ shows the particle surface of K-feldspar after $8 \mathrm{~h}$ of interaction with chicken manure. The SEM images of the surface at this magnification reveal ash particles adhering to the K-feldspar surface after interaction with fuel ash. Increasing the interaction time between K-feldspar and biomass, shown in Fig. 4c for bark and in Fig. 4e for B7C3, did not significantly influence the visible amount and size of ash particles observable with SEM.

However, the surface irregularities observed can be correlated with an increase in surface area measured via BET. The 
Fig. 3 Catalytic activity determined for layered $\mathrm{K}$-feldspar particles shown by the $\mathrm{H}_{2}$ yield relative to the WGS equilibrium

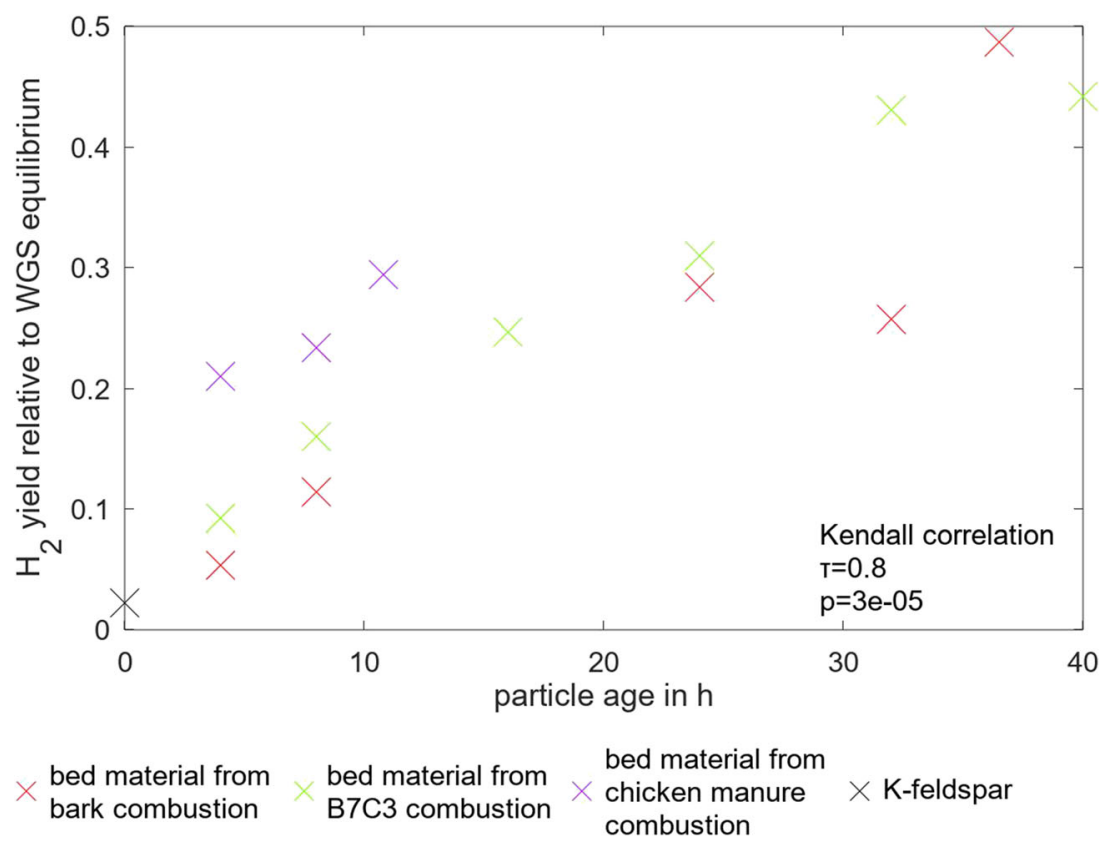

quantified results from the BET analysis are shown in Fig. 5. Fresh K-feldspar has a low surface area of around $0.4 \mathrm{~m}^{2} \mathrm{~g}^{-1}$. According to Kendall rank correlation, no correlation is given

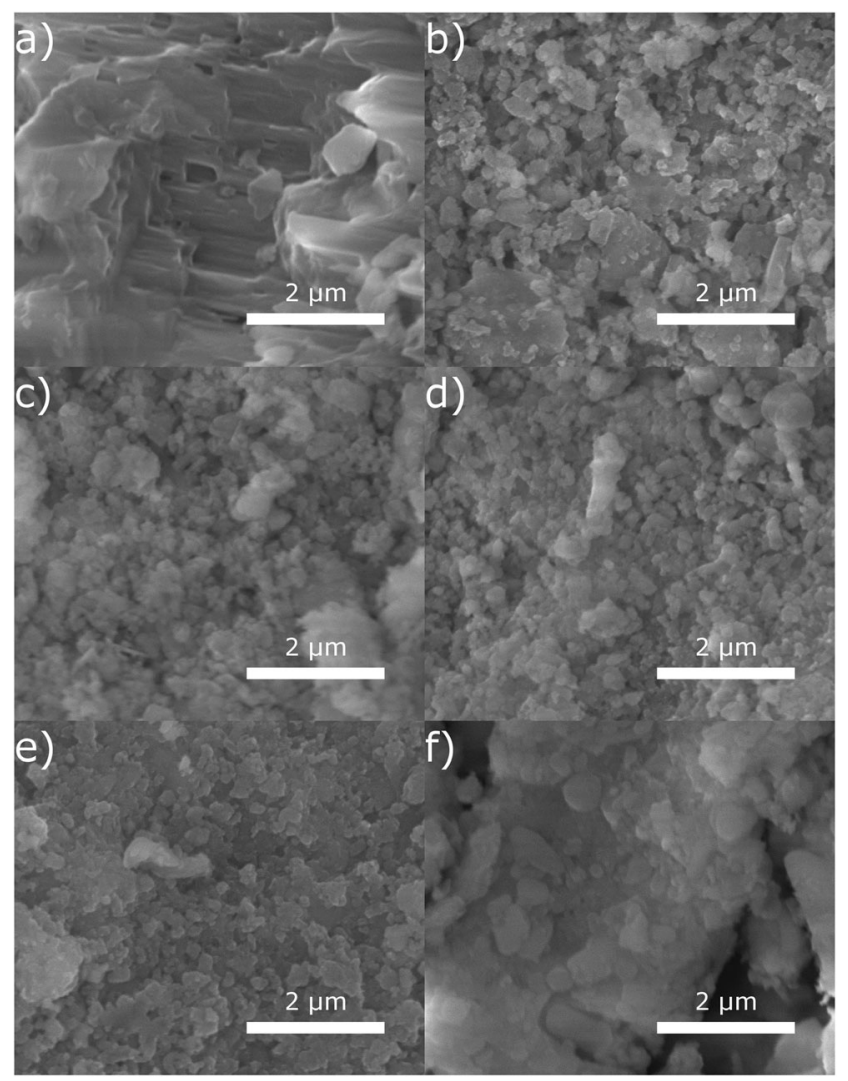

Fig. 4 SEM images of the particle surface $\mathbf{a}$ of fresh K-feldspar, $\mathbf{b}$ after $8 \mathrm{~h}$ of interaction with bark, $\mathbf{c}$ after $32 \mathrm{~h}$ of interaction with bark, $\mathbf{d}$ after $8 \mathrm{~h}$ of interaction with B7C3, e after $40 \mathrm{~h}$ of interaction with B7C3, and $\mathbf{f}$ after $8 \mathrm{~h}$ of interaction with chicken manure between the particle age and the BET surface area. Though, an increase in BET surface area can still be seen for each individual combustion experiment. The fastest increase in BET surface area was observed for chicken manure combustion, caused by the higher ash content of chicken manure $\left(0.254 \mathrm{~kg} \mathrm{~kg}^{-1} \mathrm{db}\right)$. The slowest increase in BET surface area was observed during bark combustion, the fuel with the lowest ash content studied in this study. B7C3 combustion resulted, as expected, in a surface area increase between the two pure fuels. The only reduction in BET surface area was observed after $4 \mathrm{~h}$ of bark combustion. This might be caused by the initial steps of layer formation occurring in the first hours of operation. The increase of the surface area is presumed to originate from the deposition of small ash particles on the surface. Deposit build-up of ash on the surface of the bed particles leads to a more pronounced three-dimensional landscape (see Fig. 4) which further relates to the increase in surface area.

\subsection{Surface composition}

\subsubsection{EDS}

Figure 6 shows the elemental composition measured for selected bed material samples. The ratios of $\mathrm{K}: \mathrm{Al}: \mathrm{Si}(1: 1: 3)$ measured for fresh $\mathrm{K}$-feldspar are in accordance with the crystal structure of K-feldspar (1:1:3). An enrichment of calcium in the fuel ash layers can be determined for all samples. Longer interaction times (for bark and B7C3) led to higher levels of calcium while the fraction of silicone and aluminum decreased. Inconsistent results are available for potassium; while the potassium content decreased for B7C3, it increased 
Fig. 5 BET surface area measured for bed material samples from bark, chicken manure, and $\mathrm{B} 7 \mathrm{C} 3$ combustion

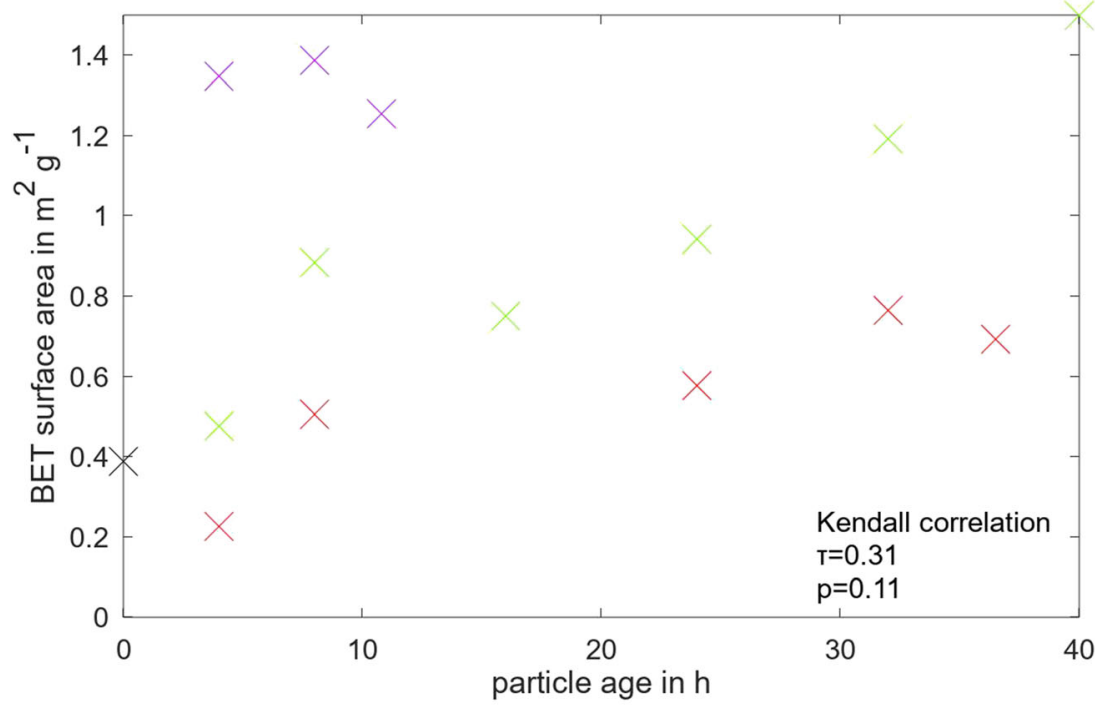

bed material from
bark combustion

bed material from B7C3 combustion

bed material from chicken manure $\times$ K-feldspar combustion for bark combustion. For the samples of chicken manure and B7C3 combustion, a considerable amount of phosphorus was detected as well. This is mostly due to the fact that more phosphorus is available in the fuel ash compared to bark. A notable amount of sulfur was also detected for the samples after chicken manure and B7C3 combustion.

\subsubsection{Phase characterization}

Table 1 summarizes all crystalline phases identified with Raman, XRD, and XPS analyses. All samples contain $\mathrm{KAlSi}_{3} \mathrm{O}_{8}$ (K-feldspar) as well as $\mathrm{SiO}_{2}$ (quartz). Several other phases containing potassium have been detected. The samples of chicken manure and B7C3 combustion contain several compounds containing phosphates; XPS measurements even detected phosphates for all samples evaluated. The presence of phosphates in fresh K-feldspar and the bark samples is surprising, since no or only little phosphorus was detected by EDS (Fig. 6). $\mathrm{K}_{2} \mathrm{SO}_{4}$, the only detected sulfur phase, was detected for the combustion of chicken manure and B7C3, caused by the higher content of sulfur in chicken manure.

Several calcium phases were detected for all layered samples, even though phases containing calcium and phosphorus were only detected for the samples from chicken manure and
Fig. 6 Elemental composition of the bed material surfaces measured by EDS

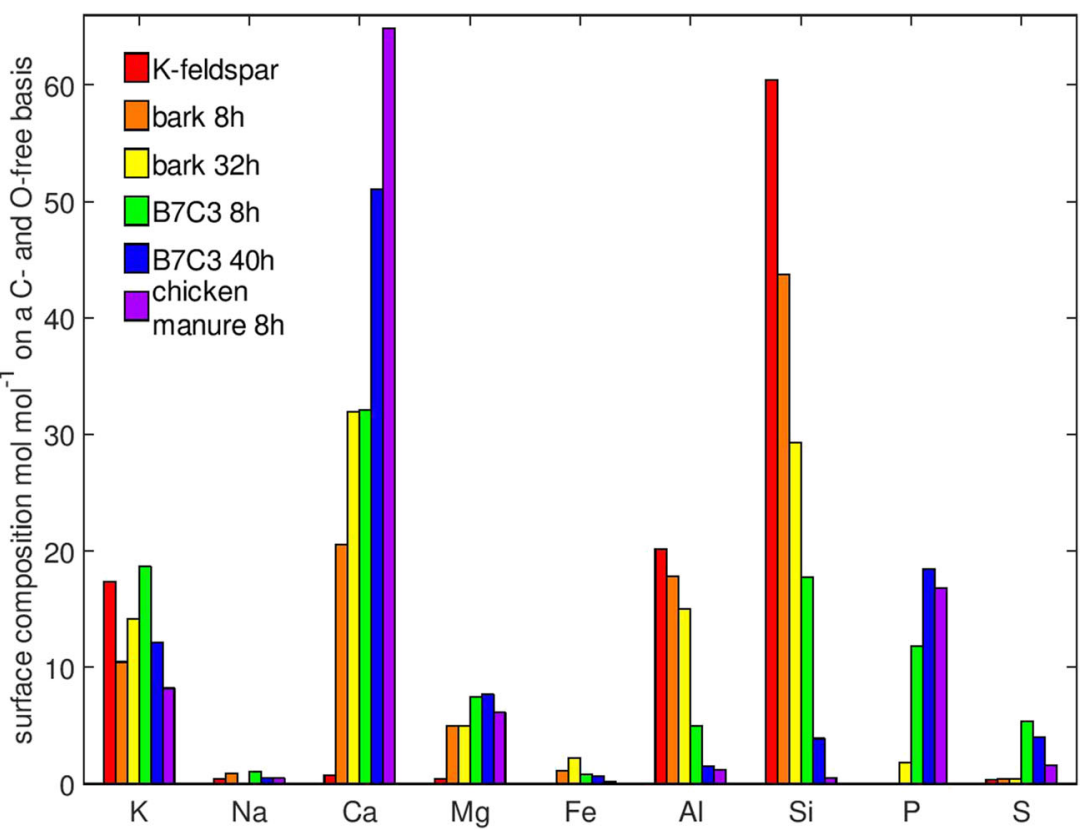


Table 1 Phases identified in the fuel ash layers by Raman, XRD, and XPS

\begin{tabular}{|c|c|c|c|c|c|c|}
\hline & Fresh K-feldspar & $8 \mathrm{~h}$ bark & $32 \mathrm{~h}$ bark & 8 h B7C3 & $40 \mathrm{~h} \mathrm{~B} 7 \mathrm{C} 3$ & $8 \mathrm{~h}$ chicken manure \\
\hline $\mathrm{SiO}_{2}$ & XPS & XRD, XPS & XRD, XPS & XPS & XRD, XPS & XRD, XPS \\
\hline $\mathrm{KAlSi}_{3} \mathrm{O}_{8}$ & XRD & XRD & XRD & XRD & XRD & XRD \\
\hline $\mathrm{K}_{2} \mathrm{SO}_{4}$ & & & & Raman & Raman & Raman \\
\hline $\mathrm{Ca}(\mathrm{Fe}, \mathrm{Mn})(\mathrm{Si}, \mathrm{Al})_{2} \mathrm{O}_{6}$ & & & XRD & XRD & & XRD \\
\hline $\mathrm{Ca}_{2} \mathrm{SiO}_{4}$ & & & & & $\mathrm{XRD}$ & XRD \\
\hline $\mathrm{CaSiO}_{3}$ & & XRD & XRD & & XRD & \\
\hline $\mathrm{CaCO}_{3}$ & & XRD & XRD, Raman & XRD, Raman & XRD & Raman \\
\hline $\mathrm{CaO}$ & & XPS & Raman, XPS & Raman & Raman & XRD, Raman, XPS \\
\hline $\mathrm{CaHPO}_{4}$ & & & & XPS & XPS & XPS \\
\hline $\mathrm{MgO}$ & & & & & & XRD \\
\hline$\left(\mathrm{CO}_{3}\right)^{2-}$ & & XPS & & XPS & XPS & XPS \\
\hline$\left(\mathrm{PO}_{4}\right)^{3-}$ & XPS & XPS & XPS & Raman, XPS & Raman, XPS & Raman, XPS \\
\hline
\end{tabular}

B7C3 combustion. $\mathrm{CaCO}_{3}$ and $\mathrm{CaO}$ were detected in all layers.

\section{Discussion}

Activation of bed material is clearly visible in Fig. 3. The activation effect that occurs due to bed material-ash interactions is well established $[37,43,44]$. The observed differences in activation potential lead to the assumption that the fuel ash content plays a role in bed material activation. With the samples available, it was not possible to get close to the equilibrium concentration of $\mathrm{H}_{2}$. Longer operational times of the fluidized bed might make it possible to reach concentrations closer to the equilibrium concentration. The final $\mathrm{H}_{2}$ yield reachable with long-term operation would give additional information on the suitability of ash-layered bed materials for biomass gasification.

As can be inferred from BET results shown in Fig. 5, higher fuel ash contents led to a faster development of an increased surface area for all the samples. This explains the reason why the surface area of the samples from chicken manure combustion reached higher BET values compared to bark combustion, even though the combustion of bark was performed for a significantly longer time frame. The positive influence of ashrich fuels on a fast bed material activation was already observed as well [24].

Figure 7 depicts the correlation between the observed BET surface area (Fig. 5) and the $\mathrm{H}_{2}$ content measured during the previously described WGS experiments (Fig. 3). Kendall rank correlation shows a strong correlation between BET surface area and the $\mathrm{H}_{2}$ yield. Higher BET surface areas have a tendency to lead to higher $\mathrm{H}_{2}$ contents in the gas. This is in accordance with the fact that higher surface areas on catalysts lead to a higher yield. The deviations from a linear correlation are probably caused by the differences in surface composition.
It can be seen that layers formed by bark combustion lead to the same $\mathrm{H}_{2}$ contents with lower BET surface areas compared to $\mathrm{B} 7 \mathrm{C} 3$ and chicken manure combustion. Studies focused on dolomite from air gasification observed a different connection between BET surface area and catalytic activity [45]. For used dolomite, the catalytic activity regarding benzene steam reforming was decreased by $24 \%$ compared to unused (but calcined) dolomite while the BET surface area increased from 0.4 to $19.5 \mathrm{~m}^{2} \mathrm{~g}^{-1}$ during gasification. They explained the results by a deactivation of the $\mathrm{CaO}$ and $\mathrm{MgO}$ sites by $\mathrm{SiO}_{2}$ deposition from the fuel ash.

EDS analysis of the layer surfaces showed differences in composition for the different fuels used for combustion. In the case of phosphorus presence in the fuel ash, the changes in surface composition can be related to the active role of phosphorus in ash transformation reactions. This is in accordance with the basic understanding of biomass ash chemistry established by Boström et al. [13]. Changes in layer composition were observed for different sampling times for bark and B7C 3 combustion. The changes in composition are mainly linked to the development of a thicker layer during operation. For the samples after $8 \mathrm{~h}$, the interference of the original Kfeldspar under the ash layer is higher compared to the interference after $32 \mathrm{~h}$ or $40 \mathrm{~h}$.

Figure 8 shows graphs depicting the $\mathrm{H}_{2}$ yield observed during the WGS experiments in dependence of the elements detected on the particle surfaces with EDS. No high correlation could be detected for any element. Though, a low correlation $(0.05<p<0.1)$ has been detected for around half of the elements.

The highest levels of calcium have been detected for chicken manure ( $8 \mathrm{~h})$ and B7C3 (40 h). According to [33], these high calcium concentrations should positively influence the catalytic activity of the bed material. Even though the amount of calcium detected on the surface of the K-feldspar after chicken manure combustion $(8 \mathrm{~h})$ was twice as high as that 
Fig. 7 Correlation between BET surface area and catalytic activity, quantified by the $\mathrm{H}_{2}$ yield regarding the WGS equilibrium

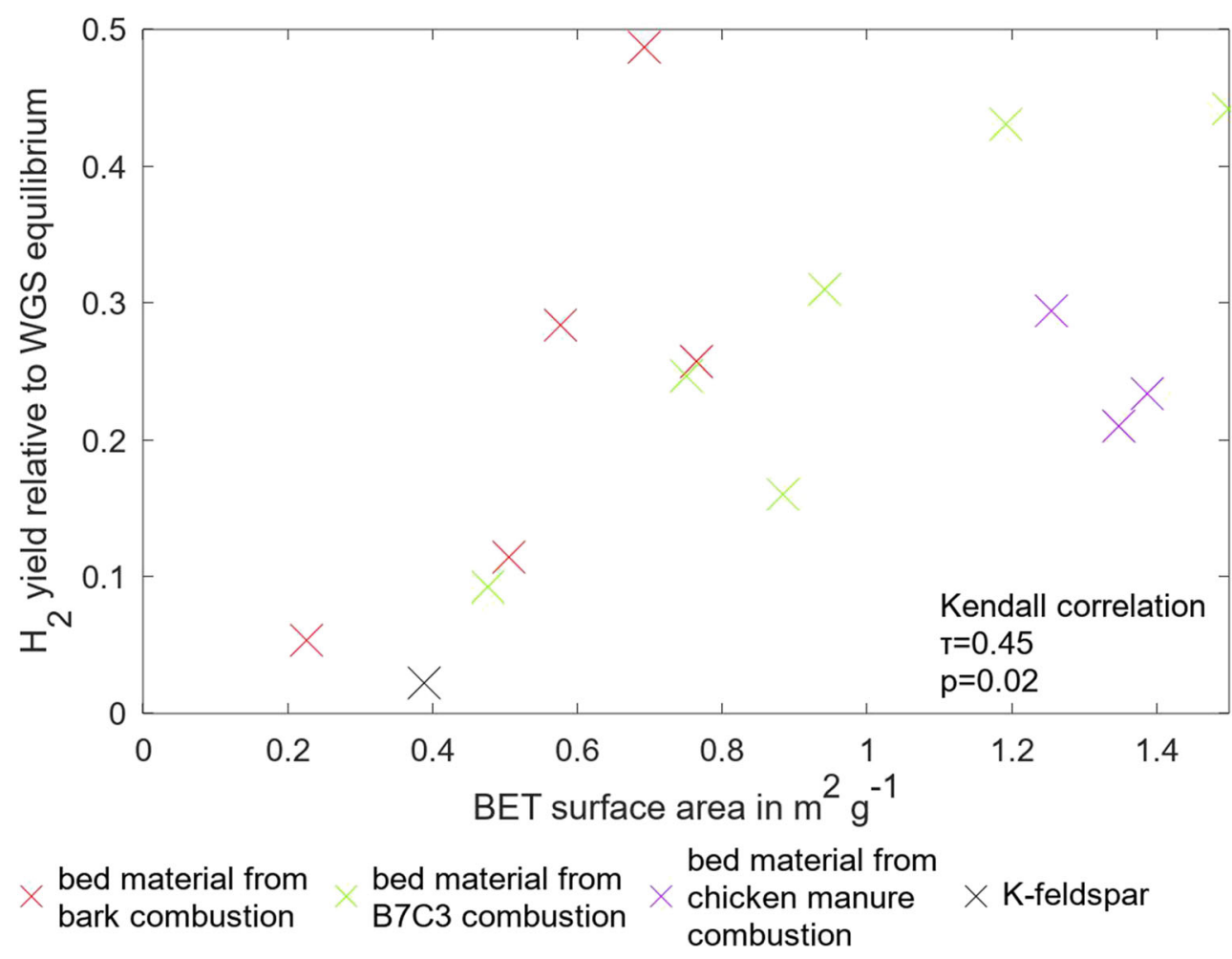

obtained after bark combustion (32 h) $\left(0.65 \mathrm{~mol} \mathrm{~mol}^{-1}\right.$ vs. $0.32 \mathrm{~mol} \mathrm{~mol}^{-1}$, respectively), it led to lower $\mathrm{H}_{2}$ contents during WGS experiments. Figure 8 also shows a low correlation between calcium and the $\mathrm{H}_{2}$ yield. A low correlation was also observed between magnesium and the $\mathrm{H}_{2}$ yield. Skodras and Sakellaropoulos attributed low contents of magnesium with a positive effect on catalytic activity [46].

Potassium is, as well, associated with a positive effect on the catalytic activity [32]. Figure 8 shows no correlation between the potassium content and the $\mathrm{H}_{2}$ yield. Therefore, it is not possible to support the positive effect of potassium on the catalytic activity with the data presented here, but it is also not possible to link it to a negative effect. Since the bed material $\mathrm{K}$-feldspar consists of potassium, the reduction in concentration is mainly caused by a dilution with other elements accumulating on the surface. This explains the tendency for lower potassium contents observed for higher $\mathrm{H}_{2}$ yields.

Sulfur and the $\mathrm{H}_{2}$ yield showed no correlation, which means that an increase in catalytic activity cannot be explained by sulfur, although sulfur has been claimed to have a positive influence on catalytic activity [32].

Low correlations of a negative impact of the silicon and aluminum on the $\mathrm{H}_{2}$ yield were detected. The negative impact is probably caused by the dilution of the silicon and aluminum stemming from the bed material and not by an actual negative effect of those elements. Further research with bed materials not containing silicon and aluminum is necessary to further support this claim.

It was not possible to correlate any other element enriching or depleting on the particle surface with the $\mathrm{H}_{2}$ yield via WGS.
Additionally, it cannot be excluded that several elements (calcium, potassium, sulfur, etc.) interact together to activate the bed material.

According to the results of XRD, XPS, and Raman analysis, there is a wide variety of phases forming for all the samples. A greater number of phases detected for the chicken manure-originating samples can be attributed to the presence of phosphorus in the fuel ash. All phases were only detected qualitatively, so only little information can be generated on the influence of combustion time on the surface phase composition. It can be said that a wider variety of phases was detected for longer operational times. This is due to the longer times available to accumulate enough of a certain phase to be above the detection limit. Häggström et al. studied ash fractions accruing during the combustion of chicken manure, a barkchicken manure mixture and a straw-chicken manure mixture [47]. Some differences can be observed when comparing the detected phases in the ash to the phases detected on the surface of the bed materials. Table 1 shows several silicates, which were not detected in the fuel ash. This is probably caused by the interaction of silicon from the K-feldspar bed material with ash components.

Due to the lack of a strong correlation between phase composition and catalytic activity, more dedicated experiments should be performed in a further study. Additional tests might also show if any phases only occurring for chicken manure and B7C3 combustion are responsible for the decreased $\mathrm{H}_{2}$ content for the same BET surface area compared to layers formed by bark combustion, as seen in Fig. 7. 

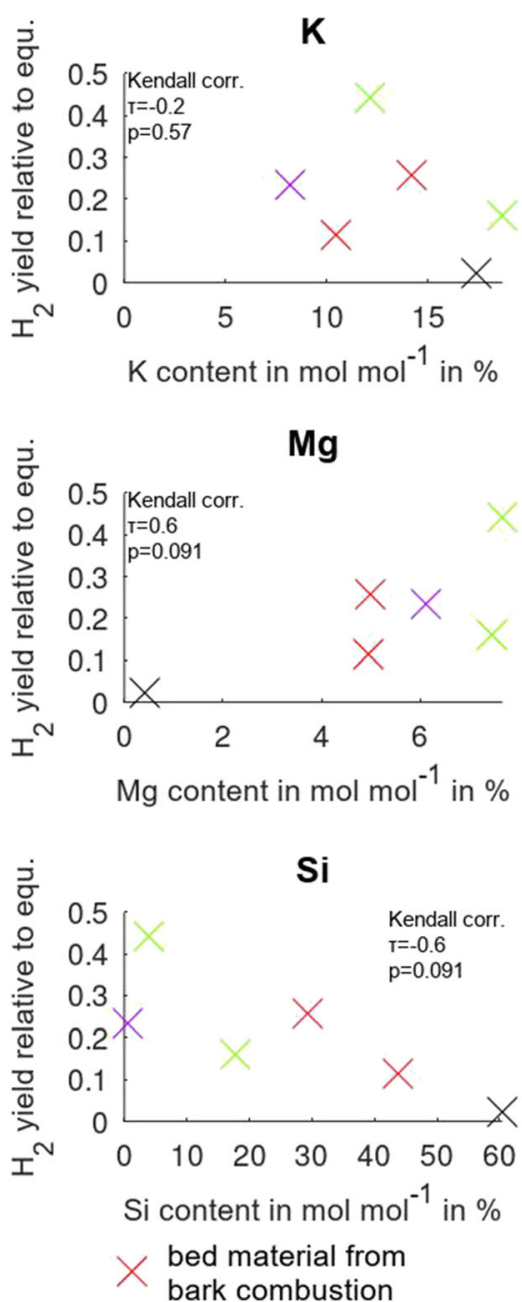
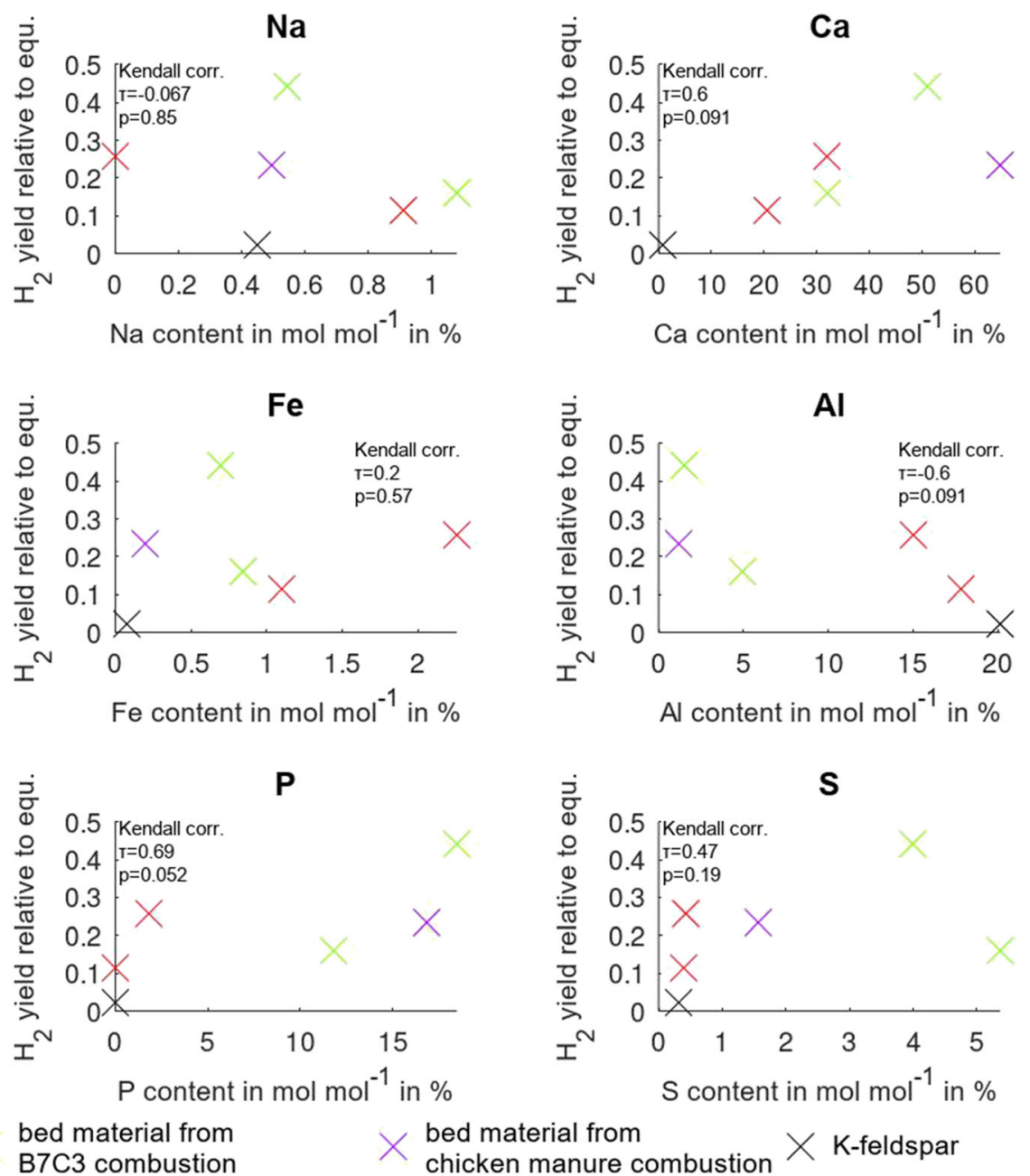

Fig. 8 Correlation between detected elements on the surface and $\mathrm{H}_{2}$ content in the gas produced during WGS experiments

Only preliminary conclusions on the role of phosphates on the surface - when phosphorus-rich biogenic residues are usedcan yet be drawn from this analytical work. The presence of phosphorus on the surface, mainly in the form of phosphates, was clearly evidenced. However, further detailed work is necessary to better correlate the phosphates to the catalytic activity.

Furthermore, it has to be emphasized here that catalytic activation is not the only possible consequence on the performance of fluidized bed gasification. An increased tendency toward agglomeration, ash deposition on heat exchangers and slagging due to significantly higher ash contents are other effects of long-term operation of fluidized bed processes. These issues need to be assessed as well before declaring the suitability of such biogenic residues for fluidized bed conversion.

\section{Conclusions}

A particular focus of this study lay in the characterization of the structure and composition of the ash layer formed upon biomass combustion and its further correlation with catalytic activity in the water-gas shift reaction. The catalytic activity was correlated to the particle age as well as the surface composition.

The following main conclusions can be drawn from the observations described in this paper:

- Through interaction with biomass, the BET surface area of the K-feldspar ash-enriched particles increased by up to $286 \%$. This is presumably due to the deposition of small ash particles leading to a more pronounced threedimensional landscape on the surface.

- Interaction with ash from bark led to the presence of a variety of crystal phases. The only phases prevalent for all samples were $\mathrm{CaO}$ and $\mathrm{CaCO}_{3}$.

- Interaction with the ash from chicken manure and a mixture of bark and chicken manure led to a more inhomogeneous surface composition compared to pure bark.

- The more inhomogeneous surface composition of Kfeldspar particles caused by the phosphorus inherent in chicken manure ash did inhibit the catalytic activation 
regarding the WGS reaction compared to the other samples. This is quantified by a decreased $\mathrm{H}_{2}$ yield for the same BET surface area.

- Still, due to the increased ash content of chicken manure and fuel blends containing chicken manure, the activation of the bed surface is occurring faster than during combustion of bark with a lower ash content.

Future work based on the present study will deal with more surface-oriented characterization of phases detected on Kfeldspar surfaces. The impact of the most common phases on the catalytic activity of bed material surfaces has to be studied in more detail. Understanding the impact of fuel ash on catalytic activity will enable a better prediction of the whole gasification process.

Acknowledgments This study was carried out within the BESTBioenergy and Sustainable Technologies GmbH project C-20-060. BEST-Bioenergy and Sustainable Technologies $\mathrm{GmbH}$ is funded within the Austrian COMET program, which is managed by the Austrian Research Promotion Agency (FFG) and promoted by the federal government of Austria as well as the federal states of Vienna, Niederösterreich, and Steiermark. We are thankful for the newly established cooperation with Jagiellonian University in Krakow and are grateful for the possibility to use Raman, XPS, and XRD analysis in the laboratories of the university and are especially thankful to M. Sitarz for the support. The authors are thankful to Pavleta Knutsson for her input and questions raised throughout the preparation of this paper.

Funding information Open access funding provided by TU Wien (TUW).

\section{Compliance with ethical standards}

Conflict of interest The authors declare that they have no conflict of interest.

Open Access This article is licensed under a Creative Commons Attribution 4.0 International License, which permits use, sharing, adaptation, distribution and reproduction in any medium or format, as long as you give appropriate credit to the original author(s) and the source, provide a link to the Creative Commons licence, and indicate if changes were made. The images or other third party material in this article are included in the article's Creative Commons licence, unless indicated otherwise in a credit line to the material. If material is not included in the article's Creative Commons licence and your intended use is not permitted by statutory regulation or exceeds the permitted use, you will need to obtain permission directly from the copyright holder. To view a copy of this licence, visit http://creativecommons.org/licenses/by/4.0/.

\section{References}

1. Steffen W, Richardson K, Rockström J et al (2015) Planetary boundaries: guiding human development on a changing planet. Science 347:1259855. https://doi.org/10.1126/science.1259855

2. World Bank; International Cryosphere Climate Initiative (2013) On thin ice: how cutting pollution can slow warming and save lives. World Bank, Washington, DC. (C) World Bank License: CC BY 3.0
IGO. https://ec2-52-21-52-208.compute-1.amazonaws.com/ handle/10986/16628

3. Statistics | World - total primary energy supply (TPES) by source (chart). In: iea. https://www.iea.org/statistics/. Accessed 20 Aug 2019

4. Basu P (2010) Biomass gasification and pyrolysis practical design and theory. Academic Press, Burlington, MA

5. Sauciuc A, Abosteif Z, Weber G, Potetz A, Rauch R, Hofbauer H, Schaub G, Dumitrescu L (2012) Influence of operating conditions on the performance of biomass-based Fischer-Tropsch synthesis. Biomass Convers Biorefinery 2:253-263. https://doi.org/10.1007/ s13399-012-0060-4

6. Fail S, Diaz N, Benedikt F et al (2014) Wood gas processing to generate pure hydrogen suitable for PEM fuel cells. ACS Sustain Chem Eng 2:2690-2698. https://doi.org/10.1021/sc500436m

7. Kraussler M, Binder M, Hofbauer H (2016) 2250-h long term operation of a water gas shift pilot plant processing tar-rich product gas from an industrial scale dual fluidized bed biomass steam gasification plant. Int J Hydrog Energy 41:6247-6258. https://doi.org/ 10.1016/j.ijhydene.2016.02.137

8. Rehling B, Hofbauer H, Rauch R, Aichernig C (2011) BioSNG process simulation and comparison with first results from a $1 \mathrm{MW}$ demonstration plant. Biomass Convers Biorefinery 1:111-119. https://doi.org/10.1007/s13399-011-0013-3

9. Thunman H, Seemann M, Vilches TB et al (2018) Advanced biofuel production via gasification - lessons learned from 200 manyears of research activity with Chalmers' research gasifier and the GoBiGas demonstration plant. Energy Sci Eng 6:6-34. https://doi. org/10.1002/ese3.188

10. Weber G, Rauch R, Hofbauer H (2015) Influence of ethylene on the formation of mixed alcohols over a MoS2 catalyst using biomassderived synthesis gas. Biomass Convers Biorefinery 5:85-94. https://doi.org/10.1007/s13399-014-0140-8

11. Karl J, Pröll T (2018) Steam gasification of biomass in dual fluidized bed gasifiers: a review. Renew Sust Energ Rev 98:64-78. https://doi.org/10.1016/j.rser.2018.09.010

12. Hofbauer H, Rauch R, Loeffler G, Kaiser S, Fercher E, Tremmel H (2002) Six years experience with the FICFB-gasification process. In: 12th European conference on biomass for energy, industry and climate protection, Amsterdam

13. Boström D, Skoglund N, Grimm A et al (2012) Ash transformation chemistry during combustion of biomass. Energy Fuel 26:85-93. https://doi.org/10.1021/ef201205b

14. Kuba M, He H, Kirnbauer F et al (2016) Mechanism of layer formation on olivine bed particles in industrial-scale dual fluid bed gasification of wood. Energy Fuel 30:7410-7418. https://doi.org/ 10.1021/acs.energyfuels.6b01522

15. He H, Ji X, Boström D et al (2016) Mechanism of quartz bed particle layer formation in fluidized bed combustion of woodderived fuels. Energy Fuel 30:2227-2232. https://doi.org/10.1021/ acs.energyfuels.5b02891

16. Berdugo Vilches T, Marinkovic J, Seemann M, Thunman H (2016) Comparing active bed materials in a dual fluidized bed biomass gasifier: olivine, bauxite, quartz-sand, and ilmenite. Energy Fuel 30:4848-4857. https://doi.org/10.1021/acs.energyfuels.6b00327

17. Wagner K, Häggström G, Skoglund N et al (2019) Layer formation mechanism of K-feldspar in bubbling fluidized bed combustion of phosphorus-lean and phosphorus-rich residual biomass. Appl Energy 248:545-554. https://doi.org/10.1016/j.apenergy.2019.04. 112

18. Kirnbauer F, Hofbauer H (2011) Investigations on bed material changes in a dual fluidized bed steam gasification plant in Güssing, Austria. Energy Fuel 25:3793-3798. https://doi.org/10. 1021/ef200746c

19. Kaknics J, Michel R, Poirier J (2016) Miscanthus ash transformation and interaction with bed materials at high temperature. Fuel 
Process Technol 141:178-184. https://doi.org/10.1016/j.fuproc. 2015.08.041

20. Grimm A, Skoglund N, Boström D, Öhman M (2011) Bed agglomeration characteristics in fluidized quartz bed combustion of phosphorus-rich biomass fuels. Energy Fuel 25:937-947. https:// doi.org/10.1021/ef101451e

21. Wagner K, Kuba M, Häggström G, Skoglund N, Öhman M, Hofbauer H (2018) Influence of phosphorus on the layer formation on K-feldspar during fluidized bed combustion and gasification. In: 26th European biomass conference and exhibition proceedings, EUBCE, Copenhagen, pp 486-492. https://doi.org/10.5071/ 26thEUBCE2018-2BO.6.2

22. Benedikt F, Schmid JC, Fuchs J et al (2018) Fuel flexible gasification with an advanced $100 \mathrm{~kW}$ dual fluidized bed steam gasification pilot plant. Energy 164:329-343. https://doi.org/10.1016/j.energy. 2018.08.146

23. Schmid JC, Benedikt F, Fuchs J, Mauerhofer AM, Müller S, Hofbauer H (2019) Syngas for biorefineries from thermochemical gasification of lignocellulosic fuels and residues -5 years' experience with an advanced dual fluidized bed gasifier design. Biomass Convers Biorefinery:1-38. https://doi.org/10.1007/s13399-01900486-2

24. Wagner K, Mauerhofer AM, Kuba M, Hofbauer H (2018) Suitability of K-feldspar as alternative bed material in dual fluidized bed steam gasification in combination with ash-rich feedstocks. Paper presented at: 23rd international conference on FBC, Seoul, Korea, 13-17 May 2018, pp 967-976

25. Wagner K, Hammerl C, Kuba M, Hofbauer H (2019) Timedependent catalytic activation of inactive K-Feldspar by layer formation during fluidized bed conversion with residual fuels. In: 27th European biomass conference and exhibition proceedings EUBCE, Lisbon, pp 779-785. https://doi.org/10.5071/27thEUBCE20192CV.2.4

26. Kuba M, Kraft S, Kirnbauer F et al (2018) Influence of controlled handling of solid inorganic materials and design changes on the product gas quality in dual fluid bed gasification of woody biomass. Appl Energy 210:230-240. https://doi.org/10.1016/j.apenergy. 2017.11.028

27. Wagner K, Häggström G, Mauerhofer AM et al (2019) Layer formation on K-feldspar in fluidized bed combustion and gasification of bark and chicken manure. Biomass Bioenergy 127:105251. https://doi.org/10.1016/j.biombioe.2019.05.020

28. Berguerand N, Marinkovic J, Berdugo Vilches T, Thunman H (2016) Use of alkali-feldspar as bed material for upgrading a biomass-derived producer gas from a gasifier. Chem Eng J 295: 80-91. https://doi.org/10.1016/j.cej.2016.02.060

29. He Z, Lane DJ, Saw WL et al (2018) Ash-bed material interaction during the combustion and steam gasification of Australian agricultural residues. Energy Fuel 32:4278-4290. https://doi.org/10.1021/ acs.energyfuels. $7 \mathrm{~b} 03129$

30. Öhman M, Pommer L, Nordin A (2005) Bed agglomeration characteristics and mechanisms during gasification and combustion of biomass fuels. Energy Fuel 19:1742-1748. https://doi.org/10.1021/ ef040093w

31. Kirnbauer F, Wilk V, Kitzler H et al (2012) The positive effects of bed material coating on tar reduction in a dual fluidized bed gasifier. Fuel 95:553-562. https://doi.org/10.1016/j.fuel.2011.10.066

32. Berdugo Vilches T, Maric J, Knutsson P et al (2018) Bed material as a catalyst for char gasification: the case of ash-coated olivine activated by $\mathrm{K}$ and $\mathrm{S}$ addition. Fuel 224:85-93. https://doi.org/10.1016/ j.fuel.2018.03.079

33. Kuba M, Havlik F, Kirnbauer F, Hofbauer H (2016) Influence of bed material coatings on the water-gas-shift reaction and steam reforming of toluene as tar model compound of biomass gasification. Biomass Bioenergy 89:40-49. https://doi.org/10. 1016/j.biombioe.2015.11.029

34. Kryca J, Priščák J, Łojewska J et al (2018) Apparent kinetics of the water-gas-shift reaction in biomass gasification using ash-layered olivine as catalyst. Chem Eng J 346:113-119. https://doi.org/10. 1016/j.cej.2018.04.032

35. Knutsson P, Maric J, Knutsson J et al (2019) Potassium speciation and distribution for the $\mathrm{K}_{2} \mathrm{CO}_{3}$ additive-induced activation/ deactivation of olivine during gasification of woody biomass. Appl Energy 248:538-544. https://doi.org/10.1016/j.apenergy. 2019.04.150

36. Knutsson P, Cantatore V, Seemann M et al (2018) Role of potassium in the enhancement of the catalytic activity of calcium oxide towards tar reduction. Appl Catal B Environ 229:88-95. https://doi. org/10.1016/j.apcatb.2018.02.002

37. Berguerand N, Berdugo Vilches T (2017) Alkali-feldspar as a catalyst for biomass gasification in a 2-MW indirect gasifier. Energy Fuel 31:1583-1592. https://doi.org/10.1021/acs.energyfuels. $6 \mathrm{~b} 02312$

38. Faust R, Hannl TK, Berdugo Vilches T et al (2019) Layer formation on feldspar bed particles during indirect gasification of wood. $1 . \mathrm{K}$ feldspar. Energy Fuel. https://doi.org/10.1021/acs.energyfuels. 9b01291

39. Hannl TK, Faust R, Kuba M et al (2019) Layer formation on feldspar bed particles during indirect gasification of wood. 2. Na-feldspar. Energy Fuel. https://doi.org/10.1021/acs.energyfuels.9b01292

40. Mauerhofer AM, Benedikt F, Schmid JC et al (2018) Influence of different bed material mixtures on dual fluidized bed steam gasification. Energy 157:957-968. https://doi.org/10.1016/j.energy. 2018.05.158

41. Kuba M, Kirnbauer F, Hofbauer H (2017) Influence of coated olivine on the conversion of intermediate products from decomposition of biomass tars during gasification. Biomass Convers Biorefinery 7:11-21. https://doi.org/10.1007/s13399-016-0204-z

42. Degen T, Sadki M, Bron E et al (2014) The HighScore suite. Powder Diffract 29:S13-S18. https://doi.org/10.1017/ S0885715614000840

43. Rauch R, Bosch K, Hofbauer H, Świerczyński D, Courson C, Kiennemann A (2004) Comparison of different olivines for biomass steam gasification. In: Proceedings of the conference for science in thermal and chemical biomass conversion, Victoria, Canada, pp 677-690. Viewed 26 August 2019, https://www. academia.edu/24146148/Comparison_of_different_olivines_for biomass_steam_gasification

44. Marinkovic J, Thunman H, Knutsson P, Seemann M (2015) Characteristics of olivine as a bed material in an indirect biomass gasifier. Chem Eng J 279:555-566. https://doi.org/10.1016/j.cej. 2015.05.061

45. Hervy M, Olcese R, Bettahar MM et al (2019) Evolution of dolomite composition and reactivity during biomass gasification. Appl Catal A Gen 572:97-106. https://doi.org/10.1016/j.apcata.2018.12. 014

46. Skodras G, Sakellaropoulos GP (2002) Mineral matter effects in lignite gasification. Fuel Process Technol 77-78:151-158. https:// doi.org/10.1016/S0378-3820(02)00063-2

47. Häggström G, Fürsatz K, Kuba M et al (2020) Fate of phosphorus in fluidized bed cocombustion of chicken litter with wheat straw and bark residues. Energy Fuel. https://doi.org/10.1021/acs. energyfuels. $9 \mathrm{~b} 03652$

Publisher's note Springer Nature remains neutral with regard to jurisdictional claims in published maps and institutional affiliations. 